\title{
Efficiency of the Extracts of Some Plants on Squash Powdery Mildew
}

\section{Ameena Moran Al Surhanee}

Assistant Professor Science Department Al Jouf University

\section{Doi:10.5901/mjss.2013.v4n11p39}

\section{Abstract}

Experiments were conducted under laboratory, greenhouse and field conditions to investigate the possible utilization of plant extracts to control Sphaerotheca fuliginea, the causal pathogen of squash powdery mildew. Six air dried plant materials, i.e. anise seeds, blue gum leaves, chamomile flowers, cumin seeds, marjoram herb and thyme herb, as well as three organic solvents (acetone, methanol, and petroleum ether) were used for extraction. Methanolic extracts (ME) of blue gum and thyme gave significant decrease in spore germination of S. fuliginea. Treating detached leaves with the organic solvents extracts (OSE) as preventive and curative treatments proved that the first was more effective than the second in controlling the disease. Spraying with (ME) of blue gum and thyme decreased powdery mildew disease incidence and increased total phenols. Also, spraying squash in greenhouse and field with the (OSE) as preventive and curative treatments gave sufficient control to the disease in most cases. However, the efficiency of the methanolic extract of thyme herb in controlling the disease as curative treatment was always comparable to that of the fungicide Afugan.

Abbreviations: (ME) Methanolic extracts, (OSE) Organic solvents extracts, (D.S) disease severity, (LSD) least significant difference, (PEE) the petroleum ether extracts, (AE) acetone extracts .

\section{Introduction}

Saudi Arabia is an arid country which is located at $16^{\circ} \mathrm{N}$ and $32^{\circ} \mathrm{E}$. Climate is characterized by long, hot, dry summer and mild, cool and short winter. The agricultural lands of Saudi Arabia, which are coarse textured containing salts to varying degrees and mostly irrigated with saline groundwater, are not considered suitable for some of the commonly grown crops (Al- Jaloud et al., 2001).

Powdery mildew of squash caused by (Sphaerotheca fuliginea, Schlect). Pollacci is the most serious disease attacked this vegetable crop. The disease causes considerable losses in yields in the field and greenhouse all over the world including Saudi Arabia (Martin, 1972; Aboul- Hayja et al., 1980; McGrath and Staniszewska, 1996; Mosa, 1997, Aly et al., 2003; Deliopoulos et al., 2008 and Kang, 2008).

The chemical fungicides have been used as the main strategy for control of powdery mildew disease and subsequently increases yield production (Abdel- Moneim et al., 1980; Keinath and DuBose, 2004; Wolf and Verreet, 2008). Unfortunately, the current and indiscriminate use of the fungicides posed a serious threat to human health, environment and production of fungicide resistant pathogen strains (McGrath, 1991; Garcia, 1993 and Durmusoglu et al., 1997 and Fernandez- Aparicio et al., 2009). The development of nontoxic alternative to chemical fungicides would be useful in reducing the undesirable effects of their uses. Fortunately, many plant extracts, including the medicinal and aromatic plants, were found to be effective in controlling squash powdery mildew disease (Ahmed, 1995; Tohamy et al., 2002; Mamdouh and Eweis, 2007 and Gilardi et al., 2008).

The antifungal substances present in the organic solvent plant extracts differed according to the solvent used in the extraction of medicinal plants (Qasem and Abu- Blan, 1996). Spraying cucurbit plants with some organic solvent plant extracts decreased the severity of powery mildew under both greenhouse and field conditions (Cheah and Cox, 1995; Paik et al., 1996; Konstantinidou and Schmitt, 1998; Tohamy et al., 2002; La Torre et al., 2004; Mamdouh and Eweis, 2007 and Remus- Borel et al., 2009).

This investigation aimed to study the effect of organic solvent extracts (OSE) of six medicinal and aromatic plants on spore germination of $\mathrm{S}$. fuliginea, the causal organism of squash powdery mildew. The effect of these (OSE) on the disease incidence and severity on detached leaves under laboratory as well as greenhouse and field conditions, was also studied. Moreover, the effect of spraying with (OSE) on squash leaves, previously inoculated with $\mathrm{S}$. fuliginea, on phenlic compounds in the leaves was determined. 


\section{Materials and Methods}

Six Saudi Arabia medicinal and aromatic plant materials namely anise seeds (Pimpinella anisum L.), blue gum leaves (Eucalyptus globules Labill.), chamomile flowers (Matiricaria chamomilla L.), cumin seeds (Cuminum cyminum L.), marjoram herb (Majorana hortensis L.) and thyme herb (Thymus vulgais L.) were used as fresh and air dried materials throughout this investigation to prepare organic solvent extracts (OSE). The finely ground air dried plant materials (25 and $50 \mathrm{gm}$ ) were soaked for $48 \mathrm{~h}$ in one liter of the used (OSE) (acetone, methanol and petroleum ether). The soaked plant materials were then extracted as mentioned by Kshirsagar and Mehta (1972).

\subsection{Laboratory experiments:}

\subsubsection{Effect of the organic solvent extracts (OSE) on spore germination of S. fuliginea:}

According to the methods described by Nair and Ellingboe (1962), powdery mildew spores of S. fuliginea (Schlect.) Pollacci, were harvested from only young leaves of summer squash (eskandarany var.). The new conidia were spread on dry clean glass slides carrying $1 \mathrm{ml}$. of each one of OSE at different concentrations Glass slides carrying $1 \mathrm{ml}$ of sterile distilled water served as control. Each slide was then placed in a U-shaped glass rod in Petri-dish lined with moistened blotting filter paper with sterile distilled water and incubated at $25^{\circ} \mathrm{C}$ for $25 \mathrm{~h}$. Five replicates were used for each treatment. After incubation, percentage of spore germination and germ tube length were determined in ten microscopic fields $(X=10 \times 40)$ for each replicate (slide). However, percentages of germinated spores were estimated according to the following formula:-

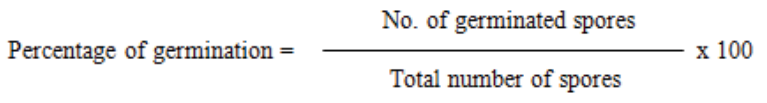

Whereas, germ tube length of germinated spore was measured using slide micrometer $2 \mathrm{~mm}$ long (2000 $\mu$ ).

\subsubsection{Effect of organic solvents plant extracts (OSE) on powdery mildew disease incidence and severity of detached leaves:}

This experiment was carried out according to the technique reported by Nagy (1983). Ten discs (each 2-cm-diam.) / Petri-dish of healthy squash leaves were placed on the polystyrene balls, then divided into groups. Discs of the first group were sprayed with each one of plant extract (50 gm/1 water) $24 \mathrm{~h}$ before inoculation with powdery mildew conidia (preventive treatment), while those of the second one were sprayed $24 \mathrm{~h}$ after inoculation (curative treatment). For control treatments, discs were sprayed with distilled water only. Four plates were used for each particular treatment. Percent of infected discs as well as disease severity were determined after 7 days from spraying, according to Townsend and Heuberger (1943) and Biswas at al. (1992).

\subsubsection{Effect of spraying leaves, infected by S. fuliginea, on their contents of phenolic compounds:}

Squash plants, naturally infected by powdery mildew, were sprayed with the plant extracts tested just after the disease symptoms appeared. Phenolic compounds in the sprayed leaves were determined colourimeterically (Snell and Snell, 1953) as follows:

a) Phosphotungstic Phosphomolybdic acid reagent: Folin and ciocalteau phenol reagent according to Snell and Snell (1953), was prepared by transferring $100 \mathrm{gm}$ sodium tungstate, $25 \mathrm{gm}$ sodium molybdate and $700 \mathrm{ml}$. of water into a $1500 \mathrm{ml}$. flask. Then, $50 \mathrm{ml}$. of $85 \%$ phosphoric acid and $100 \mathrm{ml}$. of concentrated hydrochloric acid were added, attached to a reflex condenser and boiled gently for $10 \mathrm{hrs}$., then $150 \mathrm{gm}$ of lithium sulfate $\left(\mathrm{Li}_{2} \mathrm{SO}_{4}\right), 50 \mathrm{ml}$. of water and few drops of liquid bromine were added. To remove excess bromine, the mixture was boiled without the attachment of the condenser, cooled and diluted to one liter.

b) Determination of total phenols: Total phenols were determined as follows: $2.5 \mathrm{ml}$. of concentrated HCL were added to the $0.1 \mathrm{ml}$. of the sample, heated rapidly until boiling over a free flame, with provision for condensation, and placed in a boiling water bath for 10 minutes. After cooling, $1 \mathrm{ml}$. of the reagent and $5 \mathrm{ml}$. of 
a $20 \% \mathrm{Na}_{2} \mathrm{CO}_{3}$ were added. The mixture was diluted to $10 \mathrm{ml}$. by water and after 20 minutes was determined at $520 \mathrm{~nm}$ against a reagent blank. The concentration of phenols was calculated as $\mathrm{mg}$ catechol from the standard curve.

c) Determination of free phenols: Free phenols were determined by adding $1 \mathrm{ml}$. of the reagent and $3 \mathrm{ml}$. of a $20 \%$ solution of sodium carbonate $\left(\mathrm{Na}_{2} \mathrm{CO}_{3}\right)$ to $0.1 \mathrm{ml}$. of the sample diluted to $10 \mathrm{ml}$. with warm water, 30 $35^{\circ} \mathrm{C}$, left to stand for 20 minutes and was read at $520 \mathrm{~nm}$ against a reagent blank. The concentration of phenols was calculated as previously mentioned.

d) Determination of conjugated phenols

The differences between the total and free phenols were calculated as the value of conjugated phenols.

\subsection{Greenhouse experiments}

\subsubsection{Effect of organic solvent plant extracts (OSE) on squash powdery mildew incidence and severity:}

Twenty-days-old, plants sprayed with water, were dusted with conidia of S. fuliginea by shaking mildew leaf samples over plant leaves. Plants were then sprayed with each one of the extracts tested, one week after inoculation. Plants sprayed with only tap water and Afugan fungicide[chemical formula: Diethy1- thionophospnory1) 5-methy1-6-carbethoxy pyrozolo$(1,5 a)$ pyrimidine-0,0)-2, common name: pyrazophos Manufactured by Bayer Crop science Germany - imported by agreematco Agricultural company] (1 $\mathrm{ml} / /$ water) served as control treatments. Plant extracts were sprayed four times at 7-days-interval after inoculation. Four replicates (pots) were used for each treatment and control. Inoculated pot plants were kept on wet benches until disease development was realized.

Percentages of disease incidence and severity (disease parameters) were determined after 7 days from the last spray. Percentage of infected leaves relative to the total number of leaves per plant were considered as percentages of disease incidence. Whereas, disease severity was determined according to the scale of Townsend and Heuberger (1943) and Biswas et al. (1992). Plants of each particular treatment were classified into categories as follows:

$0=$ leaves completely healthy.

$1=1-2$ spots per leaf.

$2=3-5$ spots per leaf.

$3=6-10$ spots per leaf.

$4=$ up to 25 percent of the leaf area affected.

$5=$ up to 50 percent of the leaf area affected.

$6=$ up to 75 percent of the leaf area affected.

$7=$ more than 75 percent of the leaf area affected.

The percentage of disease severity (D.S) for each particular treatment was calculated using the following formula:

$$
\text { D. } S=\frac{\text { Sum of }(\mathrm{n} \times \mathrm{v})}{\text { Total no. of leaves observed in sample } \mathrm{x} \text { max. gradings (7) }} \times 100
$$

Where

$n=$ number of infected leaves in each category.

$V=$ numerical value of each category.

The sum of numerical values were obtained by multiplying the number of leaves (observed in a particular grade) with their respective grading. Percentage of infection was determined on both upper and lower leaf surfaces and averaged.

\subsection{Filed experiments:}

\subsubsection{Effect of spraying OSE's on disease incidence and severity}

The effect of the aforementioned organic solvent extracts of six medicinal and aromatic plant extracts against squash powdery mildew disease incidence and severity were tested in the field during 2007 and 2008 growing seasons. The plants were sprayed with $50 \mathrm{gm} / \mathrm{l}$ water concentration of plant extracts as soon as the first signs of powdery mildew 
symptoms were observed on leaves. Spray treatments were repeated four times at 7-days-interval. Plants sprayed with water and Afugan fungicide served as control treatment.

Percentages of powdery mildew incidence and severity were determined seven days after the last spray following the same procedures of greenhouse experiments.

\section{Statistics}

All measurements are the means of five replicates; the results obtained were processed by analysis of variance, and the significance was determined at the least significant difference (LSD) levels of 1 and 5\% (Snedecor and Cochran, 1967).

\section{Results and Discussion}

\subsection{Laboratory experiments:}

\subsubsection{Effect of the organic solvent extracts (OSE) on spore germination of S. fuliginea:}

Data in Table (1) demonstrated that all the organic solvent plant extracts tested (OSE) were highly effective in reducing conidiospores germination and shorting germ tube length compared to the control treatment (water only). Percentages of reduction in germination were (15.77- $100 \%)$ with low dose $(25 \mathrm{gm} / \mathrm{l})$ and $(28.39-100 \%)$ in case of the high dose $(50$ $\mathrm{gm} / \mathrm{l})$. The length of germ tube was reduced by (1.85-100\%) and (9.32-100\%) with the low and high doses, respectively. The methanolicextracts (ME) of blue gum, marjoram and thyme as well as the petroleum ether extracts (PEE) of blue gum and marjoram inhibited spores germination completely at both concentrations. ( $25 \& 50 \mathrm{gm} / \mathrm{l})$, and were the superior treatments in this respect. In general, blue gum, marjoram and thyme were the best in terms of inhibitory activity, irrespective of the organic solvents and concentrations, exerting a reduction in spore germination of $33.46-100 \%$ and shortening germ tubes in the range of $8.79-100 \%$ relative to the control. Anise and chamomile as well as chamomile and cumin, however, were the least effective extracts on spore germination (15.77-53.50\% reduction) and on germ tubes length (1.85-39.19\%), respectively. As for all treatments, a significant positive correlation between the tested concentrations and the decrease in spores germination and shortening of germ tubes, was realized.

These results are in agreement with those obtained by Ahmed (1995) and Seddon \& Schmitt (1999). Whereas, the inhibitory effect of the tested organic solvent extracts might be due to the solvent used in the extraction (Qasem and AbuBlan, 1996), it is also might be due to bioactive materials present in these extracts (Taiz and Zeiger, 1991; BoghSorensen, 1994 and Nakatani, 1994).

\subsubsection{Effect of organic solvents plant extracts (OSE) on powdery mildew disease incidence and severity of detached leaves:}

Data in Table (2) showed that spraying (OSE) tested decreased powdery mildew incidence and severity on detached leaves compared to the control. Disease reduction was significant when spraying was carried out $24 \mathrm{~h}$ before (preventive treatment) or after (curative treatment) artificial inoculation. Reduction percentages in disease incidence reached (24.81$100.00 \%)$ and (6.25-37.50\%) in the preventive and curative treatments, respectively. Similar trend was experienced with the reduction in disease severity (16.86-100\% and 6.05- $42.52 \%$, respectively).

The methanolic extracts (ME) of blue gum and thyme plants completely prevented infection by powdery mildew, therefore, they were the best treatments among all the plant extracts tested.

As for the time of spraying, all (OSE) applied as a preventive treatment were more effective in decreasing infection parameters than those applied as a curative treatment. Differences between the data obtained in these two cases, were significant.

Generally, the methanolic extract was more effective than those of the acetone extract and the petroleum ether extract in decreasing powdery mildew infection parameters in case of both spraying $24 \mathrm{~h}$ before or after inoculation. However, the best treatments in the same type of solvent extract were blue gum, thyme and marjoram when applied before or after inoculation.

These results could be attributed to the antifungal compounds in the extracts, which completely precented infection in the preventive treatment (Herger et al., 1988; Ahmed, 1995; Seddon \& Schmitt, 1999 and Tohamy et al., 2002). 


\subsubsection{Effect of extracts on phenolic compound contents in S. fuliginea inoculated leaves:}

Data in Table (3) indicated that all plant extracts tested increased total phenols in leaves compared to these in the control (water only). The highest level of total phenolic compounds (1.21 mg/ gm leaves) was obtained with ME of thyme which also reflected the lowest percentage of infection and severity. The lowest $(0.69 \mathrm{mg} / \mathrm{gm}$ fresh leaves) was realized with the (ME) of anise and was accompanied with the higher infection and severity among (OSE) treatments. As regards to conjugated phenols, all treatments decreased their levels in treated leaves compared with the control, except in case of the (ME) of marjoram and thyme as well as the (PEE) of marjoram. In this respect, the (ME) of thyme gave the highest amount $(0.48 \mathrm{mg} / \mathrm{gm}$ fresh weight), while the least $(0.30 \mathrm{mg} / \mathrm{gm}$ fresh weight) was obtained with the (ME) of anise and the $(\mathrm{AE})$ of thyme. On the other hand, all treatments increased free- phenols over the control, with the highest value with the (ME) of thyme $(0.74 \mathrm{mg} / \mathrm{gm}$ fresh leaves). On the contrary, the least of $0.39 \mathrm{mg} / \mathrm{gm}$ fresh leaves was obtained with the (ME) and the (AE) of anise.

These results are in harmony with those reported by Daayf et al. (1995 and 1997) and Aly et al. (2003). This increase in total phenolic may have attributed to increase in the defense capability of plants to infection disease and development. The toxic phenolic compounds in plant cells were found to be act through: (1) the structure of bond form with cell wall components of plant tissues (Mahadevan and Sridhar, 1986), (2) enhance host resistant by stimulating host defense mechanisms (Subba Rao et al., 1988), (3) prevent the spread of fungal growth in plant tissues (Soni et al., 1992) and (4) penetrate the microorganisms and cause considerable damage to the cell metabolism (Kalaichelvan and Elangoven, 1995).

\subsection{Greenhous experiment:}

\subsubsection{Effect of organic solvent plant extracts (OSE) on squash powdery mildew incidence and severity}

Data presented in Table (4) revealed that the application of extracts as curative treatment reduced percentages of incidence and severity of powdery mildew on squash plants. In this respect, differences between these treatment and the control were always significant. Among all the plant extracts tested, the (ME) of thyme, marjoram and blue gum as well as the (PEE) of chamomile was the least effective extract against powdery mildew infection if compared with the other treatment.

The highest reduction in disease incidence (76.83\%) and severity $(68.40 \%)$ was occurred with the (ME) of thyme if compared with all treatments tested, including Afugan fungicide (control). Efficacy of that plant extract in controlling powdery mildew was approximately equal to Afugan fungicide, which reduced disease incidence and severity by $(76.12 \%)$ and $(65.57 \%)$, respectively.

Good control against powdery mildew of cucumber (S. fuliginea) using different plant extracts, including organic solvent extracts was reported by several investigators all over the world (Hano etal., 1993; Reimers et al., 1993; Steck \& Schneider, 1993; Dik et al., 1994 and Wurms et al., 1999). The success of these plant extract as effective curative treatment under adverse conditions of artificial inoculation might be attributed to their direct and/or indirect action on S. fuliginea present on the plant surfaces, disease infection and development as well as the host plant.

\subsection{Field experiment}

\subsubsection{Effect of spraying OSE's on disease incidence and severity:}

Spraying OSE's tested significantly reduced percentages of powdery mildew incidence and severity in the two experimental seasons ( 2007 \& 2008) if compared with spraying with water only (Table $5 \& 6$ and Photo 1 ).

Among all the treatments tested in both trial seasons, the (ME) of blue gum, marjoram and thyme plamt materials were the most effective in reducing powdery mildew disease parameters, without significant differences between them. However, the (ME) of anise and cumin as well as the (PEE) of anise were the least effective during the season (2007) (Table, 5). Whereas, the same reaction was recorded in the second season (2008) with the (PEE) of anise, chamomile and cumin plant materials as well as the (AE) of chamomile (Table 6).

Spraying with the (ME) of marjoram and thyme in the first season (2007) and the same type of extract of thyme at the second season (2008) were generally more effective than Afugan fungicide in reducing severity of powdery mildew. However, differences were not significant. Reductions by $(68.98 \%, 70.36 \%$ and 66.95$)$ were recorded in disease severity 
at first season when the (ME) of marjoram, thyme and Afugan were tested, respectively, whereas, they were $67.75 \%$ and $66.31 \%$ for the (ME) of thyme and Afugan respectively in second season (2008).

Qualitative and/or quantative toxicity of plant substances(S) in the (ME) of thyme herb might be more effective in controlling the disease than that of the other organic solvent extracts under field conditions (2007 and 2008). The success of this extract as effective control mean might attributed to its effect on the physiology of the causal fungus and/or host plant. In this respect, Natarajan and Lalithakumari (1987) found significant inhibition in respiration (oxygen uptake) in the fungal cells of Drechslera oryzae resulted in a general reduction of total protein, DNA and RNA as a result of the antifungal activity of plant extract.

Milsana flussing (a commercial product of plant extract as preventive treatment effectively controlled powdery mildew (S. fuliginea) of cucumber and seemed to involve the induction of plant defense responses (Herger \& Klingauf, 1990 and Daayf et al., 1997). Wurms et al. (1999) provided, however, an evidence on the appearance of localized resistance from that prophylactic compounds resulted in collapse of powdery mildew mycelial and haustoria.

Control of the disease by spraying with (ME) of thyme herp was always comparable to that of the fungicide tested. This result was similar to those reported by Rovesti et al. (1992) and Abdel-Megid et al. (2001) on powdery and downy mildew diseases, respectively. On the contrary, the fungicide Afugan was more effective than some organic solvent extracts in controlling the disease. This action might be expected because the active ingredient of this fungicide is more stable, effective and have better longevity on the plant surfaces than the biocomponents of these extracts.

Table 1: Effect of organic solvent plant extracts on spore germination criteria in lab., $24 \mathrm{~h}$. after incubation at $25^{\circ} \mathrm{C}$ and $100 \%$ relative humidity.

\begin{tabular}{|c|c|c|c|c|c|c|c|c|c|}
\hline \multirow[b]{2}{*}{ Plants } & \multirow[b]{2}{*}{ Solvent ${ }^{*}$} & \multicolumn{4}{|c|}{ Germination (\%) at plant extract conc. Of: } & \multicolumn{4}{|c|}{ Germ tube length $(\mu)$ at plant extract conc. Of: } \\
\hline & & $\begin{array}{c}25 \\
\mathrm{gm} / 1\end{array}$ & $\begin{array}{l}\text { Red.** }^{* *} \\
(\%)\end{array}$ & $\begin{array}{c}50 \\
\mathrm{gm} / 1\end{array}$ & $\begin{array}{l}\text { Red.** }^{* *} \\
(\%)\end{array}$ & $\begin{array}{c}25 \\
\mathrm{gm} / 1\end{array}$ & $\begin{array}{c}\text { Red.** }^{* *} \\
(\%)\end{array}$ & $\begin{array}{c}50 \\
\mathrm{gm} / 1\end{array}$ & $\begin{array}{c}\operatorname{Red}_{. *}^{* *} \\
(\%)\end{array}$ \\
\hline \multirow{3}{*}{ Anise } & $A$ & 52.35 & 25.02 & 45.42 & 34.95 & 37.89 & 4.00 & 34.40 & 12.85 \\
\hline & B & 48.22 & 30.94 & 32.47 & 53.50 & 24.00 & 39.19 & 16.00 & 59.46 \\
\hline & C & 58.81 & 15.77 & 40.86 & 41.48 & 32.00 & 18.93 & 30.00 & 23.99 \\
\hline \multirow{3}{*}{ Blue gum } & $A$ & 0.00 & 100.00 & 00.00 & 100.00 & 00.00 & 100.00 & 00.00 & 100.00 \\
\hline & B & 28.43 & 59.28 & 24.50 & 64.91 & 28.21 & 28.53 & 24.00 & 39.19 \\
\hline & C & 00.00 & 100.00 & 00.00 & 100.00 & 00.00 & 100.00 & 00.00 & 100.00 \\
\hline \multirow{3}{*}{ Chamomile } & A & 45.15 & 35.33 & 28.14 & 45.37 & 36.63 & 7.20 & 33.26 & 15.73 \\
\hline & B & 42.08 & 39.73 & 39.10 & 44.00 & 38.74 & 1.85 & 35.79 & 9.32 \\
\hline & C & 52.99 & 24.10 & 50.00 & 28.39 & 37.89 & 4.00 & 32.00 & 18.96 \\
\hline \multirow{3}{*}{ Cumin } & A & 57.51 & 17.63 & 39.75 & 43.07 & 32.00 & 18.93 & 30.33 & 23.16 \\
\hline & B & 35.74 & 48.81 & 30.94 & 55.69 & 28.21 & 28.53 & 24.00 & 39.19 \\
\hline & C & 50.98 & 26.98 & 45.51 & 34.82 & 36.50 & 7.52 & 32.00 & 18.93 \\
\hline \multirow{3}{*}{ Marjoram } & A & 00.00 & 100.00 & 00.00 & 100.00 & 00.00 & 100.00 & 00.00 & 100.00 \\
\hline & B & 29.67 & 57.51 & 21.81 & 68.76 & 36.00 & 8.79 & 32.00 & 18.93 \\
\hline & C & 00.00 & 100.00 & 00.00 & 100.00 & 00.00 & 100.00 & 00.00 & 100.00 \\
\hline \multirow{3}{*}{ Thyme } & $A$ & 00.00 & 100.00 & 00.00 & 100.00 & 00.00 & 100.00 & 00.00 & 100.00 \\
\hline & B & 46.46 & 33.46 & 37.08 & 46.89 & 24.00 & 39.19 & 22.00 & 44.26 \\
\hline & C & 40.73 & 41.66 & 31.40 & 55.03 & 32.00 & 18.93 & 16.00 & 59.46 \\
\hline $\begin{array}{l}\text { Control (water } \\
\text { only) }\end{array}$ & & 69.82 & - & 69.82 & - & 39.47 & - & 39.47 & - \\
\hline
\end{tabular}

* The extracted plant parts with the organic solvents; methanol (A), Acetone (B) and petroleum ether (C).

** Reduction relative to the control treatment.

L.S.D. at $5 \%$ for:

The extracted plant

Type of extract

Time of extract
(C)

EXT

$\mathrm{ExC}$

$\mathrm{T} \times \mathrm{C}$

$\mathrm{E} \times \mathrm{T} \times \mathrm{C}$
Disease inclidence

$=0.91$

$=0.46$

$\mathrm{L}=0.49$

$=1.13$

$=1.21$

$=0.86$

$=2.10$
Disease severity

$=0.06$

$=0.05$

$=0.13$

$=0.12$

$=0.33$

$=0.23$

$=0.57$ 
Table 2: Effect of organic solvent plant extracts on powdery mildew incidence and severity on detached leaves, artificially inoculated with $\mathrm{S}$. fuligines spores, $24 \mathrm{~h}$ before or after spraying.

\begin{tabular}{|c|c|c|c|c|c|c|c|c|c|}
\hline & & \multicolumn{4}{|c|}{ (\%) incidence on sprayed leaves at: } & \multicolumn{4}{|c|}{ (\%) severity on sprayed leaves at: } \\
\hline Plants & Solvent* & $\begin{array}{l}24 \mathrm{~h} \text { before } \\
\text { inoculation }\end{array}$ & $\begin{array}{l}\text { Red.** }^{* *} \\
(\%)\end{array}$ & $\begin{array}{l}24 \mathrm{~h} \text { before } \\
\text { inoculation }\end{array}$ & $\begin{array}{l}\text { Red. }^{* *} \\
(\%)\end{array}$ & $\begin{array}{l}24 \mathrm{~h} \text { before } \\
\text { inoculation }\end{array}$ & $\begin{array}{l}\text { Red. }^{* *} \\
(\%)\end{array}$ & $\begin{array}{l}24 \mathrm{~h} \text { before } \\
\text { inoculation }\end{array}$ & $\begin{array}{c}\text { Red.** }^{*} \\
(\%)\end{array}$ \\
\hline \multirow{3}{*}{ Anise } & $A$ & 50.00 & 24.81 & 59.67 & 6.77 & 36.27 & 19.74 & 39.85 & 8.37 \\
\hline & B & 40.00 & 39.85 & 50.00 & 21.88 & 33.71 & 25.40 & 39.29 & 9.66 \\
\hline & C & 43.33 & 34.85 & 56.7 & 11.45 & 36.63 & 18.94 & 40.53 & 6.81 \\
\hline \multirow{3}{*}{ Blue gum } & A & 00.00 & 100.00 & 40.00 & 37.50 & 00.00 & 100.00 & 25.00 & 42.52 \\
\hline & B & 28.00 & 57.89 & 40.00 & 37.50 & 25.00 & 44.68 & 34.23 & 21.29 \\
\hline & C & 23.33 & 46.92 & 50.00 & 21.88 & 16.95 & 62.49 & 33.40 & 23.20 \\
\hline \multirow{3}{*}{ Chamomile } & $A$ & 40.00 & 39.85 & 46.97 & 26.61 & 32.91 & 27.17 & 37.78 & 13.13 \\
\hline & B & 50.00 & 24.81 & 60.00 & 6.25 & 29.38 & 34.99 & 36.83 & 15.31 \\
\hline & C & 50.00 & 24.81 & 58.67 & 8.33 & 37.23 & 17.62 & 40.65 & 6.53 \\
\hline \multirow{3}{*}{ Cumin } & A & 46.67 & 29.81 & 55.00 & 14.06 & 37.57 & 16.86 & 40.27 & 7.40 \\
\hline & B & 33.33 & 49.88 & 50.00 & 21.88 & 32.70 & 27.64 & 38.85 & 10.67 \\
\hline & C & 50.67 & 24.81 & 60.00 & 6.25 & 37.08 & 17.95 & 40.86 & 6.05 \\
\hline \multirow{3}{*}{ Marjoram } & A & 20.00 & 69.92 & 40.00 & 37.50 & 12.50 & 72.34 & 31.83 & 26.81 \\
\hline & B & 43.33 & 34.84 & 50.00 & 21.88 & 20.82 & 53.93 & 36.94 & 15.06 \\
\hline & C & 23.33 & 64.92 & 40.33 & 37.50 & 20.45 & 54.75 & 35.23 & 18.99 \\
\hline \multirow{3}{*}{ Thyme } & $A$ & 00.00 & 100.00 & 46.67 & 27.08 & 00.00 & 100.00 & 37.48 & 13.82 \\
\hline & B & 40.00 & 39.85 & 56.67 & 11.45 & 35.11 & 22.31 & 38.63 & 11.18 \\
\hline & $\mathrm{C}$ & 36.67 & 44.86 & 56.67 & 11.45 & 25.42 & 43.75 & 34.67 & 20.28 \\
\hline $\begin{array}{c}\text { Control } \\
\text { (water only) }\end{array}$ & & 66.50 & - & 64.00 & - & 45.19 & - & 43.49 & - \\
\hline
\end{tabular}

${ }^{*}$ The extracted plant parts with the organic solvents; methanol (A), Acetone (B) and petroleum ether (C).

\section{L.S.D. at $5 \%$ for:}

The extracted plant

Type of extract

Time before or after inoculation
(E)

(T)

(C)

ExT

$\mathrm{ExC}$

$\mathrm{T} \times \mathrm{C}$

ExTxC

\section{Disease inclidence}

$$
=2.41
$$$$
=1.69
$$$$
\mathrm{L}=1.40
$$

$=4.14$

$=3.43$

$=2.80$

$=6.85$
Disease severity

$$
=0.01
$$$$
=0.80
$$

$=0.65$

$=1.96$

$=1.60$

$=1.31$

$=3.20$

Table 3: Effect of foliar spraying with organic solvent plant extracts on phenolic compound contents of leaves.

\begin{tabular}{|c|c|c|c|c|c|c|}
\hline Plants & Solvent* $^{*}$ & $\begin{array}{c}\text { Disease } \\
\text { incidence (\%) }\end{array}$ & $\begin{array}{c}\text { Disease } \\
\text { severity (\%) }\end{array}$ & Free- & $\begin{array}{c}\text { Phenolic compounds (mg/gm) } \\
\text { as:Conjugated- }\end{array}$ & Total \\
\hline \multirow{3}{*}{ Anise } & $\mathrm{A}$ & 57.50 & 64.13 & 0.39 & 0.30 & 0.09 \\
& $\mathrm{~B}$ & 39.65 & 40.19 & 0.54 & 0.35 & 0.89 \\
& $\mathrm{C}$ & 49.71 & 57.61 & 0.39 & 0.31 & 0.70 \\
\hline \multirow{3}{*}{ Blue gum } & $\mathrm{A}$ & 30.00 & 31.65 & 0.65 & 0.34 & 0.99 \\
& $\mathrm{~B}$ & 35.78 & 42.55 & 0.52 & 0.33 & 0.85 \\
& $\mathrm{C}$ & 30.88 & 33.59 & 0.63 & 0.32 & 0.95 \\
\hline \multirow{3}{*}{ Chamomile } & $\mathrm{A}$ & 38.54 & 47.69 & 0.46 & 0.33 & 0.79 \\
& $\mathrm{~B}$ & 48.03 & 43.07 & 0.50 & 0.33 & 0.83 \\
& $\mathrm{C}$ & 45.24 & 56.06 & 0.40 & 0.32 & 0.72 \\
\hline \multirow{3}{*}{ Cumin } & $\mathrm{A}$ & 50.00 & 54.31 & 0.40 & 0.35 & 0.91 \\
& $\mathrm{~B}$ & 40.53 & 38.72 & 0.55 & 0.36 & 0.75 \\
\hline & $\mathrm{C}$ & 48.17 & 55.08 & 0.40 & 0.35 & 1.12 \\
Marjoram & $\mathrm{A}$ & 29.87 & 25.02 & 0.71 & 0.41 & 0.78 \\
& $\mathrm{~B}$ & 41.26 & 50.72 & 0.43 & 0.35 & 1.21 \\
& $\mathrm{C}$ & 41.94 & 31.45 & 0.60 & 0.40 & 0.80 \\
\hline & $\mathrm{A}$ & 27.77 & 23.91 & 0.74 & 0.48 & 0.87 \\
\hline \multirow{2}{*}{ Thyme } & $\mathrm{B}$ & 38.97 & 45.06 & 0.50 & 0.30 & 0.67 \\
\hline
\end{tabular}

* Extraction from plant parts obtained with the organic solvents; methanol (A), Acetone (B) and petroleum ether (C). 
Table 4: Effect of foliar spray of OSE's on incidence and severity of powdery mildew, 7days after artificial inoculation with S.fuliginea spores under greenhouse conditions

\begin{tabular}{|c|c|c|c|c|c|}
\hline Plants & Solvent* & $\begin{array}{c}\text { Disease } \\
\text { incidence (\%) }\end{array}$ & Reduction $^{* *}(\%)$ & $\begin{array}{c}\text { Disease } \\
\text { severity (\%) }\end{array}$ & Reduction $^{* *}(\%)$ \\
\hline \multirow{3}{*}{ Anise } & A & 41.66 & 48.98 & 56.53 & 24.15 \\
\hline & B & 30.77 & 62.31 & 42.48 & 43.00 \\
\hline & C & 47.61 & 41.69 & 48.89 & 34.40 \\
\hline \multirow{3}{*}{ Blue gum } & $A$ & 21.91 & 73.17 & 31.85 & 57.27 \\
\hline & B & 40.00 & 51.01 & 37.78 & 49.31 \\
\hline & C & 26.59 & 67.43 & 31.66 & 57.52 \\
\hline \multirow{3}{*}{ Chamomile } & $A$ & 48.70 & 40.36 & 46.00 & 38.28 \\
\hline & B & 44.44 & 45.57 & 57.41 & 22.97 \\
\hline & C & 60.00 & 26.52 & 63.33 & 15.03 \\
\hline \multirow{3}{*}{ Cumin } & $A$ & 48.54 & 40.55 & 49.19 & 33.99 \\
\hline & B & 30.77 & 62.31 & 46.11 & 38.13 \\
\hline & C & 43.32 & 46.94 & 51.08 & 31.46 \\
\hline \multirow{3}{*}{ Marjoram } & A & 21.83 & 73.26 & 30.66 & 58.86 \\
\hline & B & 39.26 & 50.92 & 50.00 & 32.91 \\
\hline & C & 40.05 & 50.95 & 42.67 & 42.75 \\
\hline \multirow{3}{*}{ Thyme } & A & 18.92 & 76.83 & 23.55 & 68.40 \\
\hline & B & 27.55 & 66.26 & 31.67 & 57.51 \\
\hline & C & 32.42 & 60.29 & 40.77 & 45.30 \\
\hline \multirow{2}{*}{ Control } & Afugan fungicide & 19.50 & 76.12 & 25.66 & 65.57 \\
\hline & water only & 81.65 & - & 74.53 & - \\
\hline
\end{tabular}

*Plants were sprayed weekly for 4 weeks with methanolic extract (A), acetonic extract (B) and petroleum ether extract (C).

** Reduction relative to the control (spraying with water only).

L.S.D. at $5 \%$ for:

The extracted plant (E)

Solvent ( $\mathrm{T}$ )

ExS
Disease inclidence

$$
=5.79
$$$$
=3.18
$$

$=7.79$

\section{Disease severity}

$$
\begin{aligned}
& =2.50 \\
& =2.17 \\
& =5.31
\end{aligned}
$$

Table 5: Effect of foliar spray of OSE's on incidence and severity of powdery mildew on squash plants, grown under natural infection in the field during season 2007.

\begin{tabular}{|c|c|c|c|c|c|}
\hline Plants & Solvent* & $\begin{array}{c}\text { Disease } \\
\text { incidence (\%) }\end{array}$ & Reduction**(\%) & $\begin{array}{c}\text { Disease } \\
\text { severity (\%) }\end{array}$ & Reduction**(\%) $^{* *}$ Anise \\
\hline \multirow{3}{*}{ Blue gum } & $\mathrm{A}$ & 57.50 & 21.59 & 64.13 & 20.50 \\
& $\mathrm{~B}$ & 39.65 & 45.93 & 40.19 & 50.18 \\
& $\mathrm{C}$ & 49.71 & 32.21 & 57.61 & 28.59 \\
\hline \multirow{3}{*}{ Chamomile } & $\mathrm{A}$ & 30.00 & 59.09 & 31.65 & 60.77 \\
& $\mathrm{~B}$ & 35.78 & 51.21 & 42.55 & 47.25 \\
& $\mathrm{C}$ & 30.88 & 57.89 & 33.59 & 58.36 \\
\hline \multirow{3}{*}{ Cumin } & $\mathrm{A}$ & 38.54 & 47.44 & 47.69 & 40.88 \\
& $\mathrm{~B}$ & 48.03 & 34.50 & 43.07 & 46.61 \\
& $\mathrm{~A}$ & 45.24 & 38.31 & 56.06 & 30.51 \\
\hline \multirow{3}{*}{ Marjoram } & $\mathrm{B}$ & 50.00 & 31.82 & 54.31 & 32.68 \\
& $\mathrm{C}$ & 40.53 & 44.73 & 38.72 & 52.00 \\
& $\mathrm{~A}$ & 29.89 & 34.31 & 55.08 & 31.72 \\
\hline \multirow{2}{*}{ Thyme } & $\mathrm{B}$ & 41.26 & 59.27 & 25.02 & 68.98 \\
& $\mathrm{C}$ & 31.94 & 53.73 & 50.72 & 37.13 \\
& $\mathrm{~A}$ & 27.77 & 62.13 & 23.91 & 61.01 \\
\hline \multirow{2}{*}{ Control } & B & 38.97 & 46.86 & 45.06 & 70.36 \\
& Afugan fungicide & 13.72 & 81.29 & 26.66 & 44.14 \\
\hline
\end{tabular}


* Extraction from plant parts obtained with the organic solvents; methanol $(A)$, Acetone $(B)$ and petroleum ether $(C)$.

** Reduction relative to the control (spraying with water only).
L.S.D. at $5 \%$ for:
Disease inclidence
The extracted plant (E)
$=3.43$
Disease severity
Solvent (T)
$=3.41$
$=-2.68$
$=8.36$
$=2.21$
$=5.42$

Table 6: Effect of foliar spray of OSE's on incidence and severity of powdery mildew on squash plants, grown under natural infection in the field during season 2008.

\begin{tabular}{|c|c|c|c|c|c|}
\hline Plants & Solvent* & $\begin{array}{c}\text { Disease } \\
\text { incidence }(\%)\end{array}$ & Reduction**(\%) & $\begin{array}{c}\text { Disease } \\
\text { severity }(\%)\end{array}$ & Reduction**$(\%)^{*}$ \\
\hline \multirow{3}{*}{ Anise } & $A$ & 47.82 & 20.45 & 43.35 & 30.55 \\
\hline & $\mathrm{B}$ & 44.52 & 25.94 & 38.44 & 38.42 \\
\hline & $\mathrm{C}$ & 53.32 & 11.30 & 50.00 & 19.90 \\
\hline \multirow{3}{*}{ Blue gum } & $A$ & 25.15 & 58.16 & 24.31 & 61.05 \\
\hline & B & 42.77 & 28.85 & 36.11 & 42.15 \\
\hline & C & 28.00 & 43.42 & 26.70 & 57.23 \\
\hline \multirow{3}{*}{ Chamomile } & $A$ & 42.82 & 28.76 & 45.90 & 26.47 \\
\hline & B & 51.38 & 14.52 & 51.72 & 17.14 \\
\hline & C & 56.31 & 6.32 & 56.65 & 9.24 \\
\hline \multirow{3}{*}{ Cumin } & $A$ & 48.37 & 19.53 & 47.28 & 24.26 \\
\hline & B & 43.88 & 27.00 & 42.88 & 31.30 \\
\hline & C & 52.06 & 13.39 & 52.07 & 16.58 \\
\hline \multirow{3}{*}{ Marjoram } & $A$ & 27.18 & 54.78 & 26.17 & 58.07 \\
\hline & $\mathrm{B}$ & 47.82 & 20.45 & 47.82 & 23.38 \\
\hline & C & 38.09 & 36.63 & 36.38 & 41.72 \\
\hline \multirow{3}{*}{ Thyme } & $A$ & 24.72 & 58.88 & 20.13 & 67.75 \\
\hline & B & 37.01 & 38.42 & 33.83 & 45.80 \\
\hline & C & 47.85 & 20.40 & 45.01 & 27.89 \\
\hline \multirow{2}{*}{ Control } & Afugan fungicide & 25.38 & 57.78 & 21.03 & 66.31 \\
\hline & water only & 60.11 & - & 62.42 & - \\
\hline
\end{tabular}

* Extraction from plant parts obtained with the organic solvents; methanol (A), Acetone (B) and petroleum ether (C).

** Reduction relative to the control (spraying with water only).
L.S.D. at $5 \%$ for:
Disease inclidence
The extracted plant (E)
$=0.75$
Disease severity
Solvent (T)
$=1.18$
$=1.32$
Ex T
$=2.90$
$=1.40$
$=3.43$

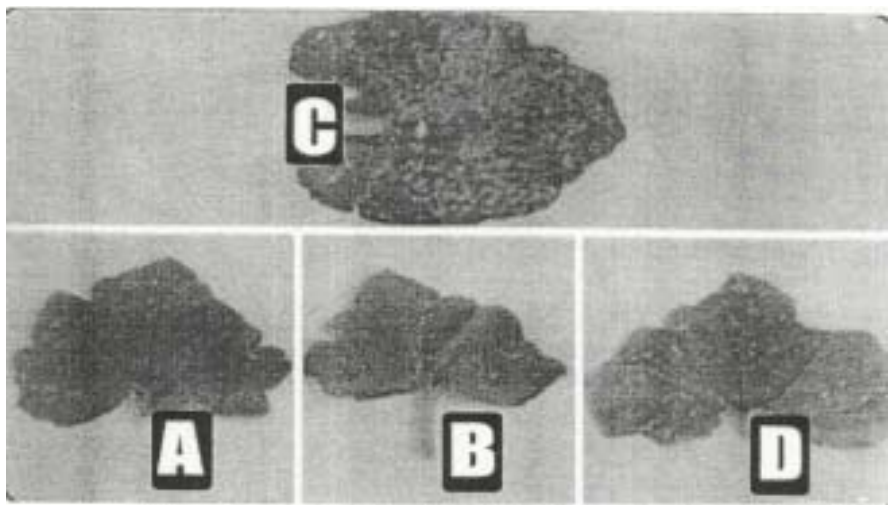

Photo 1: Effect of foliar spraying ME plant extracts on severity of powdery mildew (S. fuliginea) on squash. ME of: thyme (A), blue gum (B) and marjoram (D). $\mathrm{C}=$ Untreated control (Spraying with only water). 


\section{References}

Ahmed, S.E.Y.A. (1995): Studies on powdery mildew disease of cucurbits M.Sc. Thesis, Fac. Agric., Al-Azher Univ.

Abdel- Megid, M.S.; Mitwally, A.H; Abdel- Momen, S.M. and Hilal, A.A. (2001): A preliminary field study on the possibility of controlling foliar diseases of onion using some Egyptian medicinal plant extracts in comparison with a fungicide. Egypt. J. Phytopathol., 29(1): 21-31.

Abdel-Moneim, M.F.; Zidan, M.I. and El-Sawah, M.Y. (1980): field evaluation of some recently developed fungicides for the control of squash powdery mildew, Erysiphe cichoracearum DC. Agric. Res. Rev., 58(2): 273-281.

Abul Hayja, Z.M.; Trabulsi, I.Y.; Fathi, M. and Bahi, A. (1980): Powdery mildew in the central region of Saudi Arabia. Proc. Saudi Biol. Soc., 4: 207-217.

Al-jaloud, A.A.; Al-Saiady, M.Y.; Assaeed, A.M. and Chaudhary, S.A. (2001): Some halophyte plants of Saudi Arabia, their composition and relation to soil properties. Pakistan Journal of Biological Sciences 4(5): 531-534.

Aly, A.z; Abd El-Kader, Dawlat A.; Hilal, A.A. and Nada, M.G.A. (2003): Performance of some medicinal and aromatic plant products, especially water extracts, in controlling powdery mildew disease of squash caused by Sphaerotheca fuliginea Pollacci) of squash. Proc. 10th Cong Phytopathol. Soc., Giza, Egypt (2003), 195-217.

Bogh-Sorensen, L. (1994): Description of hurdles. In: food preservation by combined processes. L. Leistner and L.G.M. Gorris (eds.), FLAIR Report European Commission EUR 15776 EN, pp. 7-24.

Biswas, S.; Teotia, R.S. and Manal, S.K. (1992): Some field observations on the severity of powdery mildew (Phyllactinia corylea) in mulberry. Indian J. Sci., 31: 67-69.

Cheah, L.H. and Cox, J.K. (1995): Screening of plant extracts for control of powdery mildew in squash Proc. 48 th New Zealand PI. Protect. Conf., Hastings, New Zealand, pp. 340-342 (c.f. Rev. PI. Pathol., 76(7): 733, 1997).

Daayf, F.; Schmitt, A. And Belanger, R.R. (1997): Evidence of phytoalexins in cucumber leaves infected with powdery mildew following treatment with extracts of Reynoutria sachalinesis. Plant Physiol., 113(3): 719-727.

Deliopoulos, T.; Kettlewell, P.S. and Hare, M.C. (2008): Inorganic salts for suppressing powdery mildew in cucubits-a worldwide survey. Commun Agric. Appl. Biol. Sci., 73(2): 51-56.

Dik, A.J.; Van der Staay, M. and Van der Staay, M. (1994): The effect of Milsana on cucumber powdery mildew under dutch conditions Biologische Wetenschappen Universitiet Gent, 59(3a): 1027-1034 (c.f. CAB abstracts, 1993-2994).

Durmusoglu, E.; Massfeld, W. and Sengonca, C. (1997): Determination of the exposure of workers to two different pesticides in a greenhouse with roses. Mitteilungen der Deutschen Gesellschaft fur Allgemeine und Angewandte Entomolgie (German), 11: 319-322 (c.f. Rev. PI Pathol., 77(7): 716, 1998).

Fernandez-Aparicio, M.; Parts, E.; Emeran, A.A. and Rubiales, D. (2009): Characterization of resistance mechanisms to powdery mildew (Erysiohe betae) in beet (Beta vulgaris). Phytopathology. Apt; 99(4): 385-389.

Garcia, J.E. (1993): Pesticides as contaminants. Turrialba (Casta Rica), 43(3) 221 - 229 (c.f. Rev. PI Pathol., 74(6): 409, 1995).

Gilardi, G.; Gullino, M.L. and Garibaldi, A. (2008): Effect of fungicides and of biocontrol agents against powdery mildew of turnip. Commun. Agric. Appl. Biol. Sci., 73(2): 21-29.

Hano, G.; Herezig, B.; Horvath, A. and Nagy, C.Z., (1993): Study of effectively of plant extracts against different pests. Novenyvedelem, 29(3-4): 171 - 181 (c.f. CAB abstracts, 1993-1994).

Herger, G. and Klingauf, F. (1990): Control of powdery mildew fungi with extracts of the giant knotweed, Reynoutria sachalinensis (Polygonaceae). Mededelingen van de Faculteit Land bouwweteenshappen, Rijksuniversiteit, Gent., 55(3a): $1007-1014$ (c.f. CAB abstracts, 1990-1991).

Herger, G. and Klingauf, F.; Mangold, D.; Pommer, E.H. and Scherer, M. (1988): Efficacy of extracts of Reynoutria sachalinensis (F. Schmidt) Nakia against fungal disease, especially powdery mildew, Nachrichtenblatt des Deutschen Pflanzensc- hutzdienstes, 40(4): 56- 60 (c.f. CAB obstracts, 1987- 1989).

Kang, N.G. (2008): Inhibition of powdery mildew development and activation of antioxidant enzymes by induction of oxidative stress with foliar application of a mixture of riboflavin and methionine in cucumber. Scientia Horticulturae, 118: 181- 188.

Kalaichelvan, P.T. and Elangovan, N. (1995): Effect of phenolics on Drechslera oryzae, Indian Phytopathol., 48(3): 271 - 274.

Keinath, A.B. and DuBose, V.B. (2004): Evalation of fungicides for prevention and management of powdery mildew on watermelon. Crop Protection, 23: 35- 42 .

Konstantinidou, D.S. and Schmitt, A. (1998): Impact of treatment with plant extracts from Reynoutria sachalinensis (F. Schmidt) Nakia on internsity of powdery mildew severity and yield in cucmber under high disease pressure. Crop Protect., 17(8): 649-656 (c.f. Rev. PI. Pathol., 78(4): 373, 1999).

Kshirsagar, M.K. and Mehta, A.R. (1972): Survey of ferns. In Gujart State (India) for presence of antibacterial substances of ferns. Planta Medica, 22(4): 386- 390.

La Torre, A.; Spera, G. and Lolleti, D. (2004): Activity of natural products against courgette powdery mildew. Commun. Agric. Appl. Biol. Sci., 69(4): 671- 678

Martin, H.E. (1972): Report of the government of Saudi Arabia on research in plant protection. F.A.0./SAU/TF63, AGP: TA/207.

McGrath, M.T. (1991): Reduced effectiveness of triadimefon for controlling cucurbit powdery mildew associated with fungicide resistance in Sphaerotheca fluttginea. Phytopathology, 81: 1191 (Abstr).

Mosa, A.A. (1997): Effect of foliar application of phosphates on cucumber powdery mildew. Ann. Agric. Sci., Ain Shams Univ., Cairo, 42(1): 241- 255. 
Mahadevant, A. and Sridhar, K. (1986): Methods of Physiological Plant Pathoglogy. 3rd Edition. Sivakami Pub. Madras.

Mamdouh, A.M. and Eweis, M. (2007): Isolation and identification of antifungal acridone alkaloid from Ruta chalepensis L. leaves. J. Biol. Chem. Environ. Sci. 2(1): 263- 278.

McGrath, M.T. and Staniszewska, H. (1996): Management of powdewy mildew in summer quash with host resistance, disease threshold based fungicide programs or an integrated programs. Plant Dis., 80(9): 1044- 1052.

Nagy, G.S. (1983): Methods for evaluation of resistance to powdery mildews. Tagungsbericht. Akademie der Landwirtschaft swissenschaften der Deutschen Demokratischen Republisk, Hungi, 216(11): 629- 634.

Nakatani, N. (1994): Antioxidative and antimicrobial constituents of herb and species. In: Species Herbs and Edible Fungi. G. Charalambous (ed), pp. 251-271, El Sevier, Amsterdam.

Nair, K.R.S. and Ellingboe, A.H. (1962): Method of controlled inoculations with conidiospores of Erysiphe graminis var. tritici. Phytophthology, 52: 714.

Natarajan, M.P. and Latithakumari, D. (1987): Antifungal activity of the leaf extract of Lawsonia inermis on Dwechslera oryzae. Indian Phytopathol., 40(3): 390-395.

Paik, S.P.; Kyumg, S.K; Kim, J.J. and Oh, Y.S. (1996): Effect of bioactive substance extracted from Rheum undulatum on control of cucumber powdery mildew. Korean J. PI. Pathol, 12(1): 85-90 (c.f Rev. PI. Patho., 76(2): 183, 1997).

Qasem, J.R. and Abu- Baln, H.A. (1996): Fungicide activity of some common weed extracts against different plant pathogenic fungi. J. Phytopathol., 144: 157- 161.

Reimers, F.; Smolka, S.E.; Werres, S.; Plank, S.K. and Wagner, G. (1993): Effect of ajoene, a compound derived from Allium sativum, on phytopathogenic and epiphytic microorganisms. Zeitschrift fur Pflanzenkrankheiten kand Pflanzenschutzk, 100(6): 622- 2633 (c.f. CAB abstracts, 1993- 1994).

Remus-Borel, W.; Menzies, J.G. and Belanger, R.R. (2009): Aconitate and methyl aconitate are modulated by silicon in powdery mildew infected wheat plants. J. Plant Physiol., Apr; 2. (Epub ahead of print).

Rovesti, L.; Marco, S.D. and Pancaldi, D. (1992): Effect of neem kernel extract on some phytopathogenic fungi under greenhouse conditions. Zeitschrift fur Pflanzenkrankheiten and Pflanzenschutz, 99(3): 293-396 (c.f. Rev. Pl. Pathol., 71(12): 907, 1992).

Seddon, B and Schmitt, A. (1999): Integrated biological control of fungal plant pathogens using natural products. Intercept Limited, 423428 (c.f. Rev. Pl. Pathol., 78(10): 942).

Snedecor, G.W. and Cochran, W.G. (1967): Statisical Methods. Ocford and J.B.H Publishing Com. $6^{\text {th }}$ edition, pp. 593.

Snell, F.D. and Snell, C.T. (1953): Colorimetric Methods of Analysis Including Some Turbidmetric and Nepholometric Methods. D. Von Nostrad Co. Inc. Princeton, New Jersy, Toronto, New York, London, Vol. III.

Soni, G.L.; Sedha, R.K.; Khanna, P.K. and Garcha, H.S. (1992): Groth inhibition of fusarium oxysprum by phenolic compounds. Indian J. Microbiol., 32: 45-49 (c.f CAB abstracts, 1990-1993).

Steek, U. and Schneider, H. (1993): On the effect of so called (biotonics) in horticulture. Gesunde Pflanzen 45(3): 98-105 (c.f. CAB abstracts, 1993-1994).

Subba Rao, P.V.; Geigen, J.P.; Einhorn, J.; Rio, B.; Malosse, C.; Nicole, M.; Savary, S. and Ravise, A. (1988): Host defence mechanisms against groundnut rust. Internal. Arahis Newslett., 4: 16-18.

Taiz, I. and Zeiger, E. (1991): Surface protection and secondary defense compounds. In: Taiz, I. and E. Zeiger (Eds.) Plant Physiol., 318-345. Benjamin / Cummings. California.

Tohamy, M.R.A.; Aly, A.Z.; Abd El-Moity, T.H. and Abd El- Moneim, Maisa L. (2002): Evaluation of some plant extracts in controlling damping- off and mildew diseases of cucumber. Egypt. J. Phytopgathol., 30(2): 71- 80.

Townsend, G.R. and Heuberger, J.W. (1943): Methods for estimating losses caused by diseases in fungicide experiments. PI. Dis. Reptr., 27: 340- 343.

Wolf, P.F. and Verreet, A. (2008): Quaternary IPM (integrated pest management)- concept for the control of powdery mildew in sugar beets. Commun. Agric. Appl. Biol. Sci. 73(2): 57-68.

Wurms, K.; Labbe, C.; Benhamou, N. and Belanger, R.R. (1999): Effect of Milsana and benzothiazol on the ultrastructure of powdery mildew haustoria on cucumber. Phytopathology, 89 (9): 728- 736. 